\title{
Pendampingan Pemulihan Kondisi Peternakan ayam Petelur Pasca Gempa Di Kabupaten Lombok Utara
}

\author{
Dwi K. Purnamasari*, Syamsuhaidi, Erwan, dan K.G. Wiryawan \\ Fakultas Peternakan Universitas Mataram, Jl. Majapahit No. 62 Mataram 83125
}

\section{Article history}

Received: 12 Februari 2019

Revised: 01 Maret 2019

Accepted: 20 Maret 2019

*Corresponding Author:

Dwi K. Purnamasari

Fakultas Peternakan

Universitas Mataram, Jl.

Majapahit No. 62 Mataram

83125

Email: emmadkp@yahoo.com

\begin{abstract}
An earthquake that occurred from the end of July to the end of August 2018 in the province of NTB has detroyed not only residential buildings, offices, schools, religious buildings, but also livestock houses, especially the houses and cages. Almost all districts in the NTB province was affected by the earthquake and the worst affected districts were North Lombok and East Lombok. The Norty Lombok Regency is currently experiencing total paralysis both in the fields of education, government and economics and tourism. One business that requires rapid handling in the field of animal husbandry is for egg production. There are 26 poultry farmers who are members of the "Telur Jaya" breeders group supplying eggs for the community and visitors in North Lombok district. Because of the earthquake, this group was unable to produce eggs to meet the needs of the people of in North Lombok district due to destroyed housing conditions, many chickens died, and chickens which were survive received improper management and attention. The initial step taken was to recover laying hens housing and managemnt. Cage capacity for 26 breeders ranges from 250 to 2200 birds were repaired using cage materials that can still be used and new materials to replace damaged materials. Mentoring activities continue to be carried out so that poultry farmers can run their businesses so they can supply egg needs in North Lombok Regency.
\end{abstract}

Key Word: assistance, laying farmers, North Lombok Regency

\section{Abstrak}

Bencana alam gempa bumi yang terjadi sejak akhir Juli hingga akhir Agustus 2018 di propinsi NTB, telah meluluh lantahkan tidak hanya bangunan perumahan, perkantoran,pertokoan, sekolah, bangunan peribadatan bahkan perkandangan ternakpun hancur terutama kandang ayam. Kabupaten terparah akibat gempa adalah Kabupaten Lombok Timur dan Lombok Utara. Kabupaten Lombok Utara saat ini mengalami kelumpuhan total baik dari bidang pendidikan, pemerintahan, dan perekonomian, serta pariwisata. Salah satu usaha yang butuh penanganan cepat adalah bidang peternakan khususnya peternakan ayam petelur. Terdapat 26 peternak ayam petelur yang tergabung dalam kelompok peternak 'Telur Jaya', selama ini mensuplai kebutuhan telur untuk masyarakat dan para wisatawan yang berkunjung ke destinasi wisata di kabupaten Lombok Utara. Akibat gempa, kelompok ini tidak mampu lagi mensuplai kebutuhan telur dikarenakan kondisi perkandangan yang hancur, banyak ayam yang mati, dan ayam-ayam yang hidup tidak terkontrol keberadaan dan pemeliharaannya. Kegiatan pendampingan pemulihan kondisi disambut peternak dengan antusias, melalui program perbaikan (recovery) kandang ayam petelur. Perbaikan menggunakan bahan-bahan kandang yang masih bisa digunakan dan yang baru untuk mengganti bahan-bahan yang rusak. Kegiatan pendampingan terus dilakukan agar usaha peternakan ayam petelur dapat berjalan sehingga dapat mensuplai kebutuhan telur kabupaten Lombok Utara.

Kata Kunci : pendampingan, peternak ayam petelur, kabupaten Lombok Utara 


\section{PENDAHULUAN}

Pengembangan Usaha sektor peternakan khususnya peternakan ayam ras petelur merupakan usaha yang memiliki potensi yang cukup pesat. Usaha peternakan ayam petelur memberikan peranan sangat penting dalam pemenuhan kebutuhan protein hewani pada masyarakat dan berbagai keperluan industri khususnya pangan. Berdasarkan proyeksi, penduduk Indonesia tahun 2015 mencapai lebih dari 255 jutajiwa (BPS, 2014), maka kebutuhan protein hewani dapat dipastikan akan terjadi peningkatan dan hal ini memberi peluang besar bagi usaha peternakan ayam petelur sebagai penghasil telur yang merupakan sumber protein hewani.

Apabila dibandingkan dengan negara lain memang konsumsi telur rakyat Indonesia masih sangat sedikit. Menurut Agustar dan Jaswandi (2006) konsumsi telur unggas penduduk Indonesia per kapita per tahun adalah $2.7 \mathrm{~kg}$, Malaysia mencapai $14.4 \mathrm{~kg}$, Thailand $9.9 \mathrm{~kg}$, dan Filipina $6.2 \mathrm{~kg}$. Jika setiap kg telur setara dengan 17 butir, maka penduduk Indonesia baru mengkonsumsi 45.9 butir telur setiap orang per tahun atau 1 butir telur per 8 hari, penduduk Malaysia sebanyak 245 butir setiap orang per tahun atau 2 butir telur per hari. Kecilnya angka konsumsi telur ini menjadi peluang besar bagi pelaku usaha khususnya di bidang perunggasan. Industri perunggasan yang menghasilkan produk pangan memiliki prospek pasar yang sangat menjanjikan. Ke depan permintaan terhadap produk-produk peternakan unggas khususnya telur akan selalu meningkat karena beberapa faktor, yaitu pertumbuhan penduduk, peningkatan pendapatan, semakin banyaknya penduduk kelas menengah, urbanisasi, perubahan gaya hidup, dan harapan hidup.

Ayam ras petelur adalah salah satu jenis ayam yang paling banyak dipelihara oleh peternak untuk dijadikan usaha peternakan ayam petelur. Dalam pemeliharaannya, sangat ditentukan oleh faktor pakan, dimana kandungan nutrisi pada pakan harus disesuaikan dengan kebutuhan nutrisi tiap fase pertumbuhan ayam petelur. Kebutuhan gizi ayam ras petelur dikelompokkan menjadi empat kelompok umur yaitu kelompok umur 0-6 minggu (starter), 6-12 minggu (grower), 12-18 minggu (developer), dan umur lebih dari 18 minggu (layer) (Ketaren, 2010).

Telur ayam yang biasa dikonsumsi berasal dari ras ayam petelur, yang mampu memproduksi telur antara 250 - 280 butir per tahun (Zulfikar, 2013). Untuk memproduksi telur dalam jumlah banyak dan berkualitas dipengaruhi oleh beberapa faktor, salah satunya faktor pakan. Pakan juga mempengaruhi keberhasilan usaha peternakan, dimana $75 \%$ dari total biaya produksi, dihabiskan hanya untuk memenuhi kebutuhan pakan. Berbagai usaha dilakukan untuk meningkatkan kualitas telur khususnya warna kuning telur yang dihasilkan, di antaranya dengan memanipulasi pakan dengan menggunakan berbagai limbah hewani yang memiliki kandungan protein, mineral, dan kitin yang tinggi. Hasil penelitian Purnamasari, dkk. (2015) menggunakan limbah rajungan 8\% mampu meningkatkan tebal kerabang dan warna kuning telur itik. Sahara (2011) memberikan kepala udang 9\% dalam pakan mampu meningkatkan skor warna kuning telur tertinggi mencapai 10. Usaha ini dapat mengurangi pengeluaran terhadap biaya pakan yang besar dan usaha ini yang terus disosialisasikan dan dikembangkan di peternakan ayam ras petelur di kabupaten Lombok Utara propinsi NTB.

Kabupaten Lombok Utara adalah salah satu kabupaten termuda yang ada di provinsi Nusa Tenggara Barat. Kabupaten Lombok Utara pada awalnya merupakan bagian dari Kabupaten Lombok Barat yang termasuk dalam 15 (lima belas) Kecamatan yaitu Kecamatan Bayan, Gangga, Kayangan, Tanjung, Pemenang, Gunungsari, Batulayar, Narmada, Lingsar, Labuapi, Kediri, Kuripan, Gerung, Lembar dan Sekotong Tengah. Seiring dengan terjadinya perkembangan yang menuntut pelayanan 
administrasi pemerintahan dan pembangunan serta pelayanan masyarakat yang maksimal tercetus keinginan warga masyarakat Kabupaten Lombok Barat bagian Utara untuk mengusulkan pemekaran Kabupaten lombok Barat bagian Utara menjadi Kabupaten Lombok utara. Alasan pemekaran kabupaten ini adalah dalam rangka percepatan pembangunan dan pendekatkan pelayanan masyarakat yang mana dengan dipindahkannya Ibukota kabupaten Lombok Barat di Gerung berimplikasi pada semakin jauhnya jarak tempuh masyarakat Lombok Barat bagian utara ke pusat pemerintahan kabupaten (Pemerintah Kabupaten Lombok Utara, 2018).

Kabupaten Lombok Utara adalah kabupaten dengan potensi daerah yang besar, baik di bidang pertanian/perkebunan, peternakan, dan perikanan, serta pariwisata. Bidang pariwisata adalah salah satu bidang yang diunggulkan untuk dikembangkan, di mana kabupaten Lombok Utara memiliki 3 gili yang terkenal baik nasional maupun internasional, terlebih pantai senggigi yang keindahannya telah dikenal dunia. Dari tahun ke tahun kunjungan wisatawan baik domestik maupun luar negeri semakin bertambah jumlahnya.

Peningkatan bidang pariwisata ini harus didukung oleh bidang-bidang lainnya. Salah satunya adalah bidang peternakan dengan menjadikan kabupaten Lombok Utara sebagai kabupaten yang mandiri dalam penyediaan kebutuhan protein hewani baik berupa daging ternak ruminansia maupun ternak non ruminansia khususnya ayam dan telur ayam. Khususnya telur ayam, kabupaten Lombok Utara sedang dalam persiapan menuju 'Kawasan Sejuta Telur'.

Program menjadikan kabupaten Lombok Utara sebagai 'Kawasan Sejuta Telur' bertujuan untuk mensuplai kebutuhan protein hewani khususnya telur untuk kebutuhan penduduk dan kebutuhan hotelhotel di kabupaten Lombok Utara yang selama ini belum terpenuhi dan disuplai dari kabupaten lain di provinsi Nusa Tenggara Barat.

Terdapat 26 peternak ayam petelur yang tergabung dalam kelompok peternak 'Telur Jago" dengan kapasitas usaha berkisar 250-2200 ekor ayam. Selama ini kelompok peternak ini mampu mensuplai kebutuhan telur masyarakat dan para wisatawan yang berkunjung ke destinasi-destinasi wisata di kabupeten Lombok Utara. Harapan peternak ke depan mampu mensuplai kebutuhan telur di luar kabupaten Lombok Utara. Kelompok peternak 'Telur Jago' merupakan kelompok peternak binaan dari Fakultas Peternakan Unram. Berbagai kegiatan pengabdian dan penelitian seringkali diterapkan pada kelompok peternak ini. Asnawi,dkk. (2018) melaporkan hasil penelitian pemberian Suplemen Pakan Layer (SPL) pada ayam ras petelur di kelompok peternak rakyat desa Santong, mampu meningkatkan kualitas warna kuning telur yang semakin pekat dengan kadar kolesterol yang semakin rendah.

Namun bencana alam gempa bumi yang telah terjadi sejak akhir Juli hingga akhir Agustus 2018, telah memporakporandakan seluruh bangunan perumahan, perkantoran, pertokoan, sekolah-sekolah, bangunan peribadatan, serta tidak luput adalah bangunan perkandangan ternak khususnya ayam petelur. Hancurnya bangunan perkandangan menyebabkan banyak ayam-ayam yang mati tertindih oleh bangunan kandang dan ayam-ayam yang masih hidup lepas berkeliaran tidak terkontrol keberadaannya, sehingga usaha peternakan terhenti dan mengakibatkan perekonomian terpuruk. Masyarakat peternak menjadi kehilangan mata pencaharian dan kehilangan semangat dan motivasi untuk beternak lagi.

Kondisi ini tidak bisa dibiarkan lama tanpa adanya bimbingan, motivasi, dan pendampingan baik dari pemerintah daerah maupun dari akademisi. Program pendampingan diberikan kepada masyarakat peternak untuk membangkitkan semangat dan motivasi beternak secara bertahap agar masyarakat peternak secara bertahap dapat mengatasi kondisi dan tidak terpuruk terlalu lama. 


\section{METODE KEGIATAN}

Kegiatan pendampingan kelompok peternak ayam petelur 'Telur Jago' yang terdampak gempa dilakukan secara bertahap dan dimulai sejak bulan Agustus hingga bulan Nopember 2018. Tahapan kegiatan meliputi:

I. Tahapan Identifikasi potensi usaha. Pada tahapan ini dilakukan identifikasi berbagai potensi baik dari kemauan, semangat, dan keinginan untuk tetap mengembangkan usaha peternakan.

II. Melakukan verifikasi tingkat kerusakan. Pada tahapan ini dilakukan verifikasi tingkat kerusakan khususnya perkandangan ayam petelur terdampak gempa untuk dilakukan perbaikan atau recovery perkandangan.

III. Merumuskan pemecahan permasalahan dan tahapan kegiatan yang akan dilakukan. Rumusan solusi atau pemecahan masalah akan dijabarkan sesuai dengan permasalahan yang dihadapi.

Kegiatan ini berupa diskusi, wawancara, pemberian motivasi, dan bantuan, serta tindakan langsung yang melibatkan para akademisi dari Tim Pengabdian dan alumni Fakultas Peternakan Unram, serta masyarakat peternak yang tergabung dalam kelompok peternak 'Telur Jago' desa Santong kabupaten Lombok Utara.

Kegiatan pendampingan akan terus berlangsung dengan tetap melakukan komunikasi. evaluasi dan monitoring kegiatan, serta kelompok peternak ini akan terus dilibatkan tidak hanya dalam bidang pengabdian saja namun juga dalam berbagai kegiatan penelitian-penelitian yang dilakukan oleh para akademisi dari Fakultas Peternakan Unram.

\section{HASIL DAN PEMBAHASAN}

Berdasarkan hasil kegiatan pada Tahap I, yaitu melakukan identifikasi potensi usaha, maka diperoleh data jumlah peternak dan kapasitas usaha yang akan dan siap untuk terus dikembangkan, tersaji pada Tabel 1.

Tabel 1. Data Potensi Usaha

\begin{tabular}{rlcc}
\hline No. & \multicolumn{1}{c}{ Nama Peternak } & Jumlah Ayam Yang Tersisa (ekor) & Kapasitas (ekor) \\
\hline 1 & H. Nuhiryan & 300 & 2000 \\
2 & H. Bohari & 800 & 1200 \\
3 & H. Samsul & 600 & 1500 \\
4 & H. Baharuddin & 1300 & 1500 \\
5 & H. Burhanuddin & 1200 & 2200 \\
6 & Kastolani & - & 700 \\
7 & Masban & 200 & 250 \\
8 & Suhirman & 200 & 300 \\
9 & Satrianto & - & 500 \\
10 & Hasan & 350 & 350 \\
11 & Jafri & 250 & 250 \\
12 & Tohri & - & 300 \\
13 & Dahrun & - & 200 \\
14 & Hajri & - & 300 \\
15 & Hariadi & - & 800
\end{tabular}




$\begin{array}{llcc}16 & \text { Badri } & 500 & 500 \\ 17 & \text { Adi } & 200 & 200 \\ 18 & \text { Ismail Sidik } & - & 200 \\ 19 & \text { Hidayat } & 250 & 250 \\ 20 & \text { Fauzi } & - & 200 \\ 21 & \text { Ahmadin } & 500 & 500 \\ 22 & \text { Jumahir } & 300 & 300 \\ 23 & \text { Saeful } & - & 300 \\ 24 & \text { L. Hasan Basri } & - & 1000 \\ 25 & \text { Muzakkar } & - & 500 \\ 26 & \text { Sapar Wadi } & - & 250\end{array}$

Berdasarkan hasil wawancara, diskusi dan pemberian motivasi dan semangat untuk bangkit kembali memulai usaha, maka terdapat 26 peternak yang masih memiliki keinginan dan siap untuk bangkit kembali memulai usaha dengan kondisi yang ada. Pada Tabel 1 nampak kapasitas usaha yang dikelola oleh masing-masing peternak dan jumlah ayam yang masih tersisa. Terdapat 6 orang peternak yang kehilangan/kematian ayam dalam jumlah besar berkisar 700-1700 ekor, dan 13 orang peternak mengalami kehilangan/kematian ayam dalam jumlah yang tidak terlalu besar yaitu berkisar 50-500 ekor, sedangkan 7 orang peternak tidak mengalami kehilangan/kematian ayam.

Berdasarkan hasil identifikasi potensi yang ada, maka dilakukan kegiatan Tahap II yaitu melakukan verifikasi tingkat kerusakan kandang. Tingkat kerusakan kandang ayam petelur disajikan pada Gambar1.
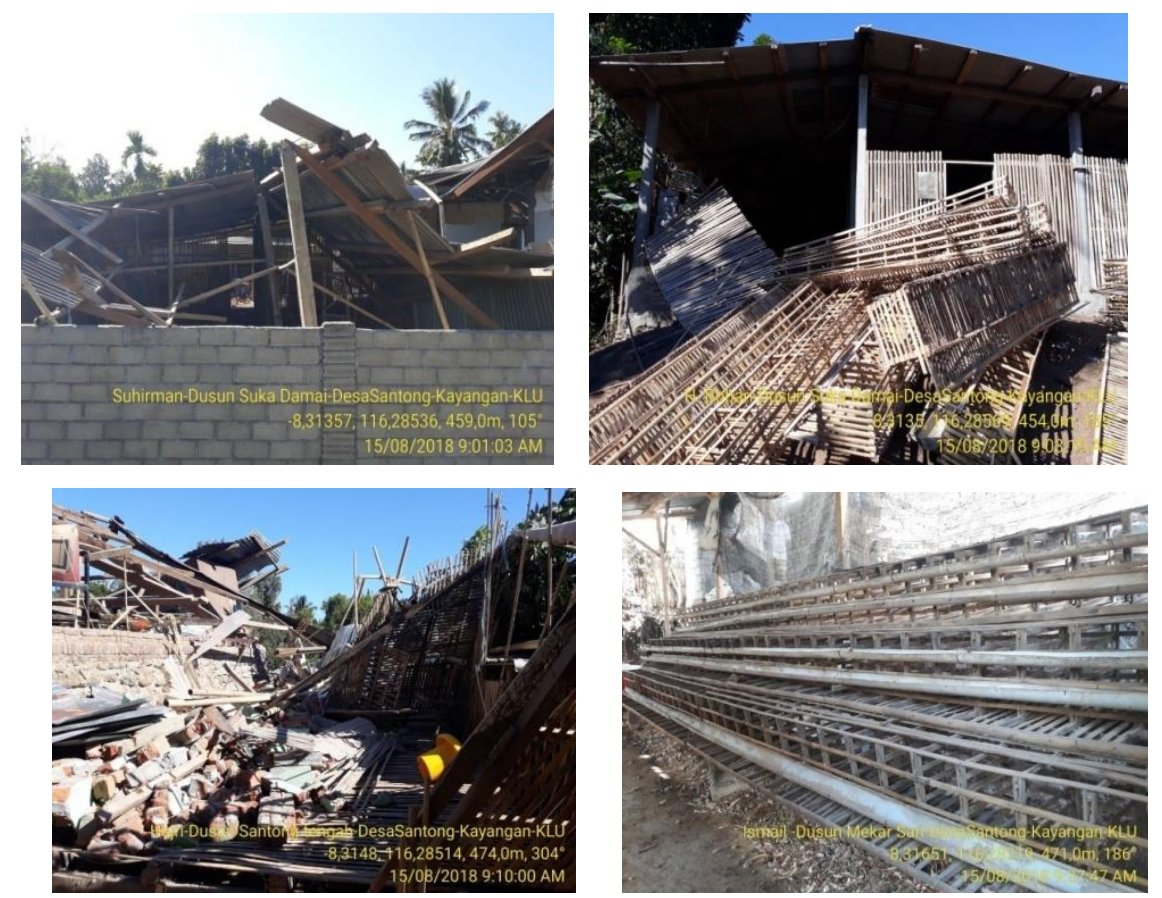

Gambar 1. Kondisi Perkandangan Ayam Petelur 
Berdasarkan hasil verifikasi tingkat kerusakan kandang, maka dikelompokkan berdasarkan tingkat kerusakan berat dan ringan. Kerusakan berat ditandai dengan hancurnya bangunan kandang dan hanya sedikit bahan bangunan yang bisa dipergunakan kembali, sedangkan tingkat kerusakan ringan ditandai dengan kerusakan yang ringan pada bangunan, ada bagian kandang, dan bahan bangunan kandang yang masih bisa dipergunakan. Data verifikasi tingkat kerusakan kandang disajikan pada Tabel 2.

Tabel 2. Data verifikasi tingkat kerusakan kandang ayam petelur

\begin{tabular}{|c|c|c|c|}
\hline \multirow[t]{2}{*}{ No. } & \multirow[t]{2}{*}{ Nama Peternak } & \multicolumn{2}{|c|}{ Tingkat Kerusakan Kandang } \\
\hline & & Ringan & Berat \\
\hline 1 & H. Nuhiryan & & $\sqrt{ }$ \\
\hline 2 & H. Bohari & & $\sqrt{ }$ \\
\hline 3 & H. Samsul & & $\sqrt{ }$ \\
\hline 4 & H. Baharuddin & & $\sqrt{ }$ \\
\hline 5 & H. Burhanuddin & & $\sqrt{ }$ \\
\hline 6 & Kastolani & & $\sqrt{ }$ \\
\hline 7 & Masban & $\sqrt{ }$ & \\
\hline 8 & Suhirman & $\sqrt{ }$ & \\
\hline 9 & Satrianto & & $\sqrt{ }$ \\
\hline 10 & Hasan & $\sqrt{ }$ & \\
\hline 11 & Jafri & $\sqrt{ }$ & \\
\hline 12 & Tohri & & $\sqrt{ }$ \\
\hline 13 & Dahrun & & $\sqrt{ }$ \\
\hline 14 & Hajri & & $\sqrt{ }$ \\
\hline 15 & Hariadi & & $\sqrt{ }$ \\
\hline 16 & Badri & $\sqrt{ }$ & \\
\hline 17 & Adi & $\sqrt{ }$ & \\
\hline 18 & Ismail Sidik & & $\sqrt{ }$ \\
\hline 19 & Hidayat & $\sqrt{ }$ & \\
\hline 20 & Fauzi & & $\sqrt{ }$ \\
\hline 21 & Ahmadin & $\sqrt{ }$ & \\
\hline 22 & Jumahir & $\sqrt{ }$ & \\
\hline 23 & Saeful & & $\sqrt{ }$ \\
\hline 24 & L. Hasan Basri & & $\sqrt{ }$ \\
\hline 25 & Muzakkar & & $\sqrt{ }$ \\
\hline 26 & Sapar Wadi & & $\sqrt{ }$ \\
\hline
\end{tabular}

Terdapat 9 orang peternak yang mengalami kerusakan kandang ayam dalam kategori ringan dan sisanya sebanyak 17 peternak mengalami kerusakan kandang dalam kategori berat. Berdasarkan hasil verifikasi tingkat kerusakan kandang maka dilakukan diskusi Tahap III yaitu merumuskan pemecahan masalah dan tahapan kegiatan yang akan dilaksanakan. Hasil diskusi pada Tahap III ditabulasi dan disajikan pada Tabel 3. 
Tabel 3. Perumusan masalah dan pemecahan masalah

\begin{tabular}{|c|c|c|c|}
\hline No. & $\begin{array}{c}\text { Perumusan } \\
\text { Masalah }\end{array}$ & Pemecahan Masalah & Respon Peternak \\
\hline 1 & $\begin{array}{lr}\text { Umumnya } & \text { peternak } \\
\text { mengalami } & \text { penurunan } \\
\text { semangat bekerja } & \end{array}$ & $\begin{array}{l}\text { Melakukan pertemuan } \\
\text { dan diskusi-diskusi }\end{array}$ & $\begin{array}{l}\text { Peternak mulai } \\
\text { termotivasi dan semangat } \\
\text { untuk bangkit kembali }\end{array}$ \\
\hline 2. & Kerusakan perkandangan & $\begin{array}{l}\text { Pengumpulan kembali } \\
\text { bahan-bahan kandang } \\
\text { yang masih bisa } \\
\text { terpakai dan pemberian } \\
\text { bantuan untuk } \\
\text { pembelian bahan-bahan } \\
\text { kandang yang baru }\end{array}$ & $\begin{array}{l}\text { Peternak sangat senang } \\
\text { dan semangat untuk } \\
\text { membangun kembali } \\
\text { bangunan perkandangan } \\
\text { dan memulai usaha } \\
\text { secara bertahap }\end{array}$ \\
\hline 3 & Kesulitan Pakan Ayam & $\begin{array}{l}\text { Menghubungkan } \\
\text { dengan pemerintah } \\
\text { terkait untuk } \\
\text { mendapatkan bantuan } \\
\text { berupa pakan ternak }\end{array}$ & $\begin{array}{l}\text { Peternak antusias } \\
\text { menyambut adanya } \\
\text { kesiapan pemerintah } \\
\text { dalam menyalurkan } \\
\text { bantuan pakan walaupun } \\
\text { secara bertahap }\end{array}$ \\
\hline 4 & $\begin{array}{l}\text { Peternak butuh terus } \\
\text { pendampingan dan } \\
\text { informasi-informasi } \\
\text { pengetahuan dan teknologi } \\
\text { untuk meningkatkan usaha } \\
\text { peternakan }\end{array}$ & $\begin{array}{l}\text { Tim pengabdian siap } \\
\text { memberikan } \\
\text { pendampingan, } \\
\text { informasi-informasi, } \\
\text { dan kerjasama dengan } \\
\text { kelompok peternak }\end{array}$ & $\begin{array}{l}\text { Peternak siap untuk } \\
\text { diajak kerjasama }\end{array}$ \\
\hline
\end{tabular}
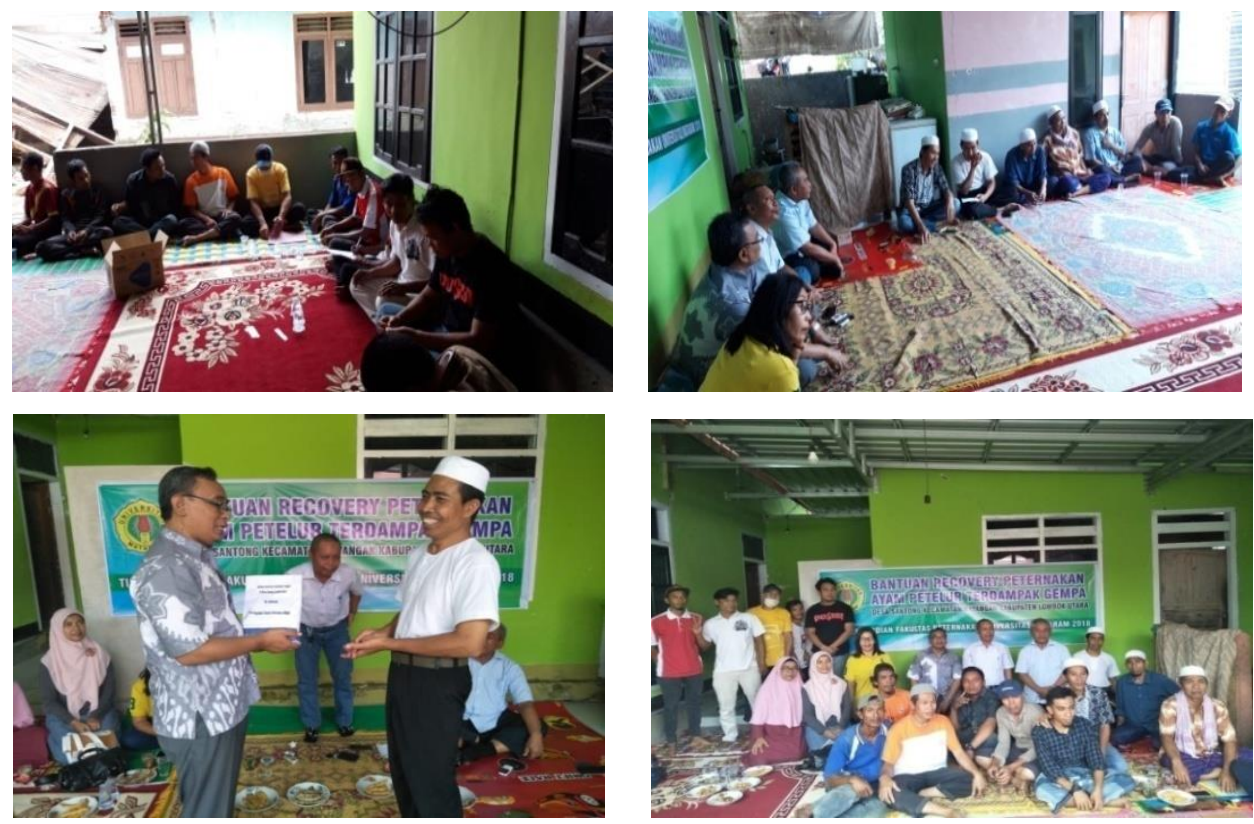

Gambar 2. Suasana Diskusi dan Pemberian Bantuan Recovery Kandang 
Diskusi tim pengabdian Fakultas Peternakan Unram dengan anggota kelompok peternak berlangsung dengan lancar dihadiri oleh seluruh anggota peternak dan peternak sangat antusias dan semangat untuk bangkit kembali memulai usaha secara bertahap. Situasi diskusi antara tim pengabdian Fakultas Peternakan Unram dengan kelompok peternak ‘Telur Jago’ nampak pada Gambar 2.

\section{KESIMPULAN}

Dari hasil kegiatan pengabdian ini dapat disimpulkan:

1. Peternak memiliki semangat dan respon yang tinggi terhadap kegiatan pendampingan ini dan bersemangat untuk bangkit kembali untuk mengembangkan usaha ayam petelur.

2. Adanya komitmen untuk segera memperbaiki kandang dan memulai usaha beternak ayam petelur dan tetap menjalin kerjasama dengan pihak akademisi.

3. Kelompok peternak unggas yang ada perlu mendapat perhatian yang serius baik dari Akademisi maupun dari Dinas instansi terkait dalam pembinaan terhadap kelompok peternak unggas secara terus menerus/ berkesinambungan.

\section{Ucapan Terima Kasih}

Ucapan terima kasih disampaikan kepada Tim Pengabdian Fakultas Peternakan,alumni, dan masyarakat peternak yang telah bersedia bekerja sama untuk bangkit kembali membangun kabupaten Lombok Utara khususnya dalam bidang peternakan.

\section{DAFTAR PUSTAKA}

Agustar, A dan Jaswandi. 2006. Potensi Sapi Lokal Dalam Upaya Mewujudkan Kecukupan Daging Dan Pengembangan Kawasan Peternakan. Jurnal Peternakan Indonesia, 11(3): 181-187.

Asnawi, M. Ichsan, dan D.K. Purnamasari. 2018. Penerapan Produk Supplement Pakan Layer (SPL) Guna Meningkatkan Produktifitas dan Kualitas Telur Ayam Ras Petelur Pada Peternakan Rakyat Di desa Santong Lombok Utara. Prosiding Seminar Nasional 2018. Lombok Plaza Hotel Mataram, 27 Oktober 2018. ISBN:9786025366901

BPS. 2014. Statistik Indonesia 2014. Biro Pusat Statistik. Jakarta.

Ketaren, P.P. 2010. Kebutuhan Gizi Ternak Unggas Di Indonesia. Wartazoa. Vol. 20.No. 4 Th. 2010.

Pemerintah Kabupaten Lombok Utara. 2018. Profil Kabupaten Lombok Utara. http://lombokutarakab.go.id. Diakses tanggal 10 April 2018

Purnamasari, D.K., K.G. Wiryawan, Erwan, \& L.A. Paozan. (2015). Potensi Limbah Rajungan (Portunus pelagicus) Sebagai Pakan Itik Petelur. Jurnal Peternakan Sriwijaya. Vol. 4 No.1. Juni 2015, pp. 11-19.

Sahara, E. 2011. Penggunaan Kepala Udang Sebagai Sumber Pigmen dan Kitin Dalam Pakan Ternak. J. Agrinak. 1(1): 31-35.

Zulfikar, 2013. Manajemen Pemeliharaan Ayam Petelur Ras. Jurnal Lentera vol. 13, No. 1 (2013). www.jurnal.muslim.ac.id. 